\title{
Harvard, Again: Considering Articulation and Accreditation in Rhetoric and Composition's History
}

Ryan Skinnell

"The first modern composition program was begun at Harvard, with President Charles W. Eliot as its sponsor and his classmate Adams Sherman Hill as its creator. Other colleges quickly followed Harvard's lead, but it is to Harvard that we must look for the rationale behind the rise of composition." John C. Brereton, The Origins of Composition Studies (8-9)

Early generations of rhetoric and composition historians, including such notable scholars as Albert Kitzhaber, James Berlin, and Sharon Crowley, traced the "birth" of first-year composition (FYC) to Harvard in the 1880s. ${ }^{1}$ Following Kitzhaber, this Harvard narrative ${ }^{2}$ became the field's de facto origin story and has long functioned as an "“always already' beyond which it can be difficult to go" (Donahue 222). Later generations of historians challenged the Harvard narrative, turning to local, archival research at alternative sites (e.g., normal schools; women's colleges) using less traditional sources (e.g., lecture notes; diaries) as a way of demonstrating the breadth of history informing contemporary writing teachers (see, e.g., Fitzgerald; Gannett, Brereton, and Tirabassi; Gold; Sullivan). As a result, rhetoric and composition historians have moved away from considering Harvard as "progenitor" and shifted toward "[situating] it within an expanded analytical framework as one of many possible sites of pedagogical innovation" (Donahue 223). Although the impulse to situate Harvard in an expanded framework is prudent, I contend that the continued focus on pedagogical innovation rehearses a disciplinary tendency to ignore institutional issues - that is, concerns about the operations and 
advancement of the institution - that shaped innovative pedagogy. In this essay I return again to Harvard and the "birth" of first-year composition. My goal, however, is not to further explore Harvard as a site of pedagogical innovation, but instead to consider two institutional issues that shaped FYC's emergence: articulation and accreditation.

Drawing on research I conducted in Harvard's University Archives, as well as on published materials, I argue that FYC emerged as a requirement at Harvard largely because of faculty and administrators' attempts to address institutional issues. In particular, I argue that a central concern for Harvard administrators in the late 1880s was articulation. Articulation is the institutional protocol for connecting two or more types of schools (e.g., secondary and postsecondary) so that students can move between them by virtue of well-defined processes. Archival materials at Harvard, including reports, correspondence, and presidential papers, indicate that Harvard's FYC requirement was intended to facilitate articulation with secondary schools to attract new crops of students. Attracting new students allowed administrators to address a number of other institutional issues, such as transforming Harvard College into Harvard University.

Focusing on institutional issues such as accreditation is a valuable addition to what historians understand about FYC at Harvard, and it is also valuable for comprehending common issues that existed across multiple institutions. The institutional (articulation) issues that Harvard hoped to address vis-à-vis first-year composition predominated in American education at institutions both elite and otherwise. My initial focus on articulation at Harvard points to issues affecting nineteenth century American education institutions on a national scale: relationships among secondary and post-secondary schools, enrollment concerns, demands to standardize educational objectives, and attempts to enhance articulation. It also points to institutional 
mechanisms implemented to address these issues. Concurrent with the introduction of FYC, Harvard administrators and faculty became involved accreditation.

Accreditation is an extra-institutional system of standards, usually established by an external association or agency, designed to ensure that similar institutions meet similar criteria for quality. In light of pervasive articulation concerns, accreditation associations began forming in the 1880s, and Harvard officials were among the leading voices in the movement. In the second part of this essay, therefore, I turn my attention to accreditation. I contend that Harvard's success in addressing articulation vis-à-vis FYC, coupled with Harvard officials' active involvement in developing accreditation, resulted in accreditation associations adopting FYC as a viable tool for addressing institutional issues on a national scale.

Although articulation and accreditation, and institutional issues like them, were not expressly concerned with writing instruction, they had profound effects on how writing instruction developed in American higher education. A focus on institutional issues such as articulation and accreditation, therefore, represents an important addition to rhetoric and composition histories. As Donna Strickland points out in The Managerial Unconscious, disciplinary histories have tended to focus primarily on developments in writing and the teaching of writing to the exclusion of larger institutional issues (4-5). Even when such issues are addressed, they are generally offered as contextual rather than determinative. For example, in The Evolution of College English, Thomas Miller introduces articulation and accreditation (131134), but despite his recognition of their importance, Miller ultimately subordinates them to disciplinary considerations in line with his specific purposes. ${ }^{3}$ Revisiting rhetoric and composition's history with an institutional focus, however, directs historians' attention to significant concerns in higher education that profoundly shaped FYC as it developed into a 
national requirement. By purposefully investigating institutional issues, historians can revisit important questions about how first-year composition came to exist, how and why it became ubiquitous in higher education, and, therefore, how we might better understand rhetoric and composition in the contemporary academy.

\section{Composition in Cambridge}

Although Harvard officials were not using the term, articulation was a central concerns for administrators and faculty in the late nineteenth century. Administrators especially were invested in aligning and strengthening connections between different types of schools in order to recruit applicants and retain matriculants. By 1882, Harvard offered—and assumed the total costs for-entrance examinations in eight cities around the country to give qualified applicants the chance to apply (Eliot "Entrance"; "Annual Report, 1882-1883” 20-21). Harvard's president, Charles W. Eliot, was particularly invested in articulation. Over the course of his 40-year tenure as president (1869-1909), Eliot worked consistently to facilitate articulation between public high schools and Harvard, and I contend that his focus on articulation ultimately resulted in the establishment of FYC.

Eliot's investment in articulation was evident long before FYC was introduced at Harvard. In his 1869 "Inaugural Address,” Eliot discussed education reforms that were of concern "not only to the university, but to the preparatory schools of every grade down the primary" (4). Eliot's interest in articulation resulted at least partly from his obligation to attract larger numbers of students to Harvard. A small, steady supply of matriculants came from preparatory schools, but as Eliot's papers make clear, Harvard's progress as an institution required an increased supply of students drawn from sources beyond traditional New England feeder schools and academies (Eliot, “Address, Tenth” 79; Collar, “Action” 426-427; 
VanOverbeke 24). Eliot made this case about post-secondary institutions at large in an 1896 speech at the Convention of the Association of Colleges and Preparatory Schools: "[I]f we want to get into our colleges and technical schools more than this small percentage of all the secondary school pupils [trained in endowed academies and preparatory schools]," he writes, "higher institutions must make connection with the public high school" (“Address, Tenth" 79). Eliot's speech to the association members was in keeping with a long tradition of attempts to increase post-secondary enrollments at Harvard, one which reflected an even longer tradition by Harvard administrators to develop the college into a university (“Annual Report, 1883-1884" 1112). The transformation from college to university required several steps, the foremost of which was increasing enrollments $(46){ }^{4}$

Drawing more applicants to Harvard entailed overcoming significant challenges, especially the lack of connection between public high schools and colleges. Eliot gave a speech in 1884, entitled "Present Relations of Mass. High Schools to Mass. Colleges," in which he argued that a major problem with linking secondary schools to colleges was "diverging aims of the high school and the college" $(20) .{ }^{5}$ Eliot delineated several causes of divergence, the most pressing of which was that secondary schools felt forced to choose whether to prepare students for life (that is, careers) or for college, but felt they could not do both. ${ }^{6}$ Schools prepared students for life via modern subjects, including mathematics, modern languages, and natural and physical sciences. College preparation, however, traditionally required classical training in ancient languages. These divergent curricular options impeded articulation among schools and colleges because colleges were not well suited to accepting non-classical students, nor were they well suited to meeting non-classical students' educational needs. So students who attended nonclassical high schools were discouraged from attending colleges for lack of classical preparation. 
Eliot's principal solution for facilitating closer articulation between secondary and postsecondary schools was reforming college admission requirements. He wrote, "The rigidity of the college requirements for admission," by which he meant classical training, "make[s] the position of the high school more and more precarious, and its work of preparation for college less and less adequate" ("Present" 20). Consequently, he lobbied for admission requirements "of reasonably wide options, so that some course or courses of study which will admit [students] to colleges may be brought almost to coincide with a substantial high-school course of study, laid out primarily for youth who are not going to college" (20). His argument was essentially for better articulation. He asserted in numerous addresses and essays that if colleges' admissions requirements were more flexible, secondary schools could consolidate curricula to include classical and modern subjects to the benefit all students ("Secondary" 23; "Address, Classical"; "Shortening"; see also "Annual Report, 1885-1886" 7-9). Students would thereby be freed from what Eliot considered a premature choice between "life" and "college."

Attempts to strengthen articulation were not isolated to Eliot or Harvard. There was a distinct lack of standardization in American education on a national scale. The education system had expanded precipitously but unevenly in the mid-1800s, so that following the Civil War, "[t]he point where higher education began and secondary schools left off remained unclear and ambiguous" (VanOverbeke 11). In fact, the line between secondary schools, colleges, and other schools was hardly a line at all. Elementary schools, secondary schools, academies, religious schools, normal schools, colleges, universities, and more, often taught overlapping curricula and competed for students (VanOverbeke 21). The lack of standardization was problematic for a number of reasons, ${ }^{7}$ but one prominent concern was that ill-defined objectives stymied attempts to forge connections between institutions - that is, it hindered articulation. 
According to education historian Marc VanOverbeke, one of the great crusades of nineteenth century education reformers, including Eliot, was establishing the now-familiar American education hierarchy in which elementary and secondary schools, specifically public ones, prepared students to attend colleges and universities. Reformers believed that such a hierarchy would standardize objectives for each level of education, reduce competition for students, and result in more efficient education (e.g., Eliot, "Elementary"). Contrary to popular belief, "[N]either secondary nor higher education had sufficient power or authority to compel the other to embrace unwanted reforms" (VanOverbeke 2). ${ }^{8}$ The education hierarchy, however, appealed to many education reformers at both levels. It appealed to post-secondary reformers because colleges and universities needed to increase enrollments in order to stay viable, ${ }^{9}$ and having high schools feed them was advantageous. It appealed to secondary reformers, especially as the status of secondary school credentials decreased following the spread of compulsory education laws, because it reduced competition between high schools and colleges/universities, both in terms of curriculum and enrollments. Of course, reforming education into a hierarchy demanded well-defined connections between secondary and post-secondary institutions to smooth students' transitions.

Rhetoric and composition historians will likely recognize that Eliot's efforts to recruit students were contemporaneous with Adams Sherman Hill's attempts to get required composition moved to Harvard's first year. For many years, Hill sought to move the Sophomore English requirement to the freshman year, but his attempts were routinely "defeated in the Faculty" (Committee on Rhetoric 7). For Eliot's part, there is no indication that he was especially interested in first-year composition as such. Rather, he was invested in articulation with secondary schools. FYC eventually came to serve his purpose, but for many years, Eliot 
focused his energy on other efforts. One such effort was introducing entrance exams in either classical or modern subjects. As early as 1876, Eliot sought to reduce Greek and Latin and offer entrance exams in math and science ("Annual Report, 1876-1877" 58-59). ${ }^{10}$ By the end of the 1870s, Harvard implemented new exam options along these lines. To complement the new examinations, Eliot lobbied aggressively for elective curricula that included classical and modern options. According to Harvard historian, Samuel Eliot Morison, the elective system was one of Charles W. Eliot's "primary aims" (xlii). Eliot felt so strongly about the elective system that in an 1885 speech at Brown University, he proclaimed "election of studies was the only way to make real scholarship possible" ("Address, Elective" 3; "Experience”). By the early 1880s, Eliot's vision for attracting non-classical students was being realized: Harvard applicants elected admissions exams and matriculants elected courses in line with their professional ambitions. Eliot's efforts toward reforming Harvard's admissions and curricula are crucial for considering how FYC came to be a requirement. One problem with Eliot's elective system was that students came to Harvard with very different educational backgrounds. As a consequence, many administrators and faculty felt it necessary to retain some small number of requirements in the first year in order to address matriculants' varied preparations. FYC became one such requirement. By 1884, Harvard's required courses were all in the first year. They were: rhetoric, English Composition (themes and forensics), German or French, and lectures on chemistry and physics ("Annual Report, 1883-1884" 5; Harvard 73). ${ }^{11}$ As noted, articulation links the objectives of different schools to allow students to move between them. As it turns out, FYC provided one such link. In fact, FYC explicitly linked Harvard's objectives to the diverse curricular objectives of secondary institutions.

The conviction that FYC could facilitate articulation is apparent in two Harvard Board of 
Overseers' committee reports, as are some reasons why FYC might be an appealing option for doing so. The first report was issued by Harvard's "Special Committee on Rhetoric and English" in 1883 . The committee was formed to "report what measures may be expedient or practicable to remedy the unsatisfactory condition" of the Department of Rhetoric and English Literature (Committee on Rhetoric 1). According to the report, the English department's "unsatisfactory condition" resulted from limited options for students to study English language and literature. The committee's diagnosis is as follows:

Remembering that there is no profession of employment which the graduate of Harvard College is likely to adopt in which the ability to write and speak his own language well will not be most valuable, and that in many it is almost essential to success, the committee cannot feel that the condition of the English Department is satisfactory. It would seem almost as if the study of English were discriminated against in the arrangement of the college course. (4)

The committee report hints at why more English instruction is especially desirable-language skills are "almost essential for success" in the rapidly changing world outside Harvard's walls.

The report also explains how to meet the desire. The committee's prescription includes: (a) changing admissions requirements "to insure greater attention in preparatory schools to the study of English literature ... and the practice of composition"; (b) making English composition "part of the prescribed work in the Freshman year"; and (c) offering more composition throughout the college course (4-5). These recommendations were quickly adopted and ultimately brought FYC into official existence (“Annual Report, 1883-1884" 83-85). The committee's diagnosis and prescription are striking because they gesture to inducing deeper study of English in secondary schools, but they point most strenuously to Harvard's obligation to 
extend English instruction, especially in writing and speaking, beyond where secondary schools left off. The report expressly calls for realigning Harvard's composition curriculum to facilitate articulation with non-classical secondary schools.

The second report, "Report of Committee Elective System," was published in 1886, two years after FYC was introduced, to consider the effects of the first-year requirements. The committee writes, "A course of preparatory study ... is indispensible for securing the best results in more advanced study. The preparatory schools alone cannot supply it, and to do so remains therefore an important function of the earlier stages of college life" (Committee on Requisitions 5). The authors conclude that election of freshman studies should continue in a limited existence but should not be extended any further. One requirement this recommendation attempted to safeguard, though not explicitly mentioned, was first-year composition.

The attempt to protect FYC, along with the unequivocal statement that colleges needed to offer preparatory study, indicates FYC's role in articulation. FYC provided an "indispensible" bridge between secondary and post-secondary studies because it was flexible enough to serve the diversely prepared students that Harvard's progressive elective system attracted. The same sentiment is repeated in the 1886-1887 "Annual Report" in which Eliot notes that FYC helped "to make the instruction in English at school and college continuous. Before ... there was always a break of one year, and often of two years, in the continuity of the instruction in English,- - to the great disadvantage of the student" (6-7). In contrast, Eliot contended that English language instruction—especially writing instruction—should carry through "the end of the university course" ("Elementary" 35). In short, FYC was designed to help achieve an institutional goal—in this case, extending Harvard's curriculum to enable articulation with secondary schools. 
Of course, these reports show that FYC was not solely a mechanism of articulation. Per the Board of Overseers, composition was designed to facilitate students' success within the elective system (Committee on Requisitions 4). Eliot wrote, "The exercises in English composition ... have been modified and brought into connection with the elective courses which the student is pursuing; so that, instead of being disputations upon topics quite foreign to his main work, they tend to become essays upon subjects to which he is devoting a great part of his time” (“Annual Report, 1883-1884” 5). ${ }^{12}$ Harvard administrators hoped students would connect composition to elective courses instead of taking a decontextualized composition course to which they would never refer. This is not to say that FYC did not serve the gate-keeping function often noted by rhetoric and composition historians, but at least officially, Eliot and the Overseers supported FYC because it facilitated institutional advancement by way of articulation and because they believed it would be as pedagogically sound as it was institutionally sound.

Harvard officials did not specifically refer to FYC as a form of articulation, but it quite clearly was. In addition to explicitly linking the last year of secondary school to the first year of college, FYC also served students with divergent preparatory educations and post-secondary goals. FYC assumed the burdens of reducing pressure on secondary schools; aligning Harvard as a successor to secondary schools; and bridging the gap between secondary and post-secondary instruction to facilitate students' success. In effect, FYC was a form of curricular relationship building, and its introduction at Harvard marks a shift in American education more generally, in which educators (broadly defined) began rethinking education institutions in relation to one another. As I argue below, this shift had tremendous consequences for the expansion of FYC nationally.

\section{Accrediting Composition}


Focusing on articulation as Eliot's pet hobby helps historians to recognize distinctive institutional conditions in which Harvard's FYC requirement came to exist. What historians have not often been able to account for, however, is how a requirement like first-year composition moves between institutions despite distinctive local circumstances. Given the notoriously slow pace of change in higher education, the expansion of FYC as a universal requirement following Harvard's adoption happened much more rapidly than might be expected. Fifteen years elapsed between Charles Eliot's identification of English as a suitable subject of collegiate study in 1869 ("Inaugural") and Harvard's introduction of first-year composition. According to rhetoric and composition historians, it took just sixteen additional years for FYC to become a national requirement (Brereton 13). ${ }^{13}$

Historians have developed various theories for explaining FYC's spread. A common assumption has been that large numbers of colleges followed Harvard's example (e.g., Connors; Stewart). Other historians, notably the contributors to Patricia Donahue and Gretchen Flesher Moon's Local Histories, suggest that composition existed in several institutions prior to or concurrent with Harvard's introduction of FYC. But historians have not yet developed a convincing explanation for how FYC became codified so quickly at the end of the nineteenth century. Donahue notes as much in her call to study “the 'migration' of [A.S] Hill's text, the nature of its incorporation, and the nature of its transformation" (231). It might seem that FYC was "in the air" owing to a broad consensus about student writers' deficiencies, but broad consensus hardly explains a near-universal education policy revolution in less than two decades. Focusing on institutional issues, however, can help us understand how FYC went from a local manifestation — a tool for Harvard administrators to address specific exigencies— to a near- 
universal requirement in higher education. In this section, again drawing on archival and published materials, I contend that accreditation offers a better explanation.

The articulation challenges Harvard faced, especially aligning secondary and postsecondary institutions and standardizing objectives, were national ones. Although individual institutions developed strategies for articulating with secondary schools, it quickly became clear that articulation needed to encompass multiple institutions if it was going to be effective. In New England, classical preparatory schools agitated for better alignment with colleges beginning in the 1870s because "the movement among New England colleges toward an increase of admission requirements, both in quantity and in quality, had proceeded so far as to press somewhat severely on the preparatory schools" ("Editorial" 548; Brown 570). Public high schools, as noted above, had different concerns about articulation. Harvard's attempt to address public high school's concerns with electives did not address the variety of admissions requirements across multiple colleges and universities. The solution that developed was accreditation.

Accreditation was originally introduced at the University of Michigan in 1870, and the explicit goal was articulation: faculty visited and "accredited" secondary schools, which allowed graduates to attend the university without taking entrance exams (VanOverbeke 37). The Michigan system proved burdensome, but accreditation gained traction as a mechanism for articulation. In place of Michigan's system, professional associations developed in the last three decades of the nineteenth century to address similar objectives. These associations were designed to facilitate closer connections between secondary and post-secondary institutions to the benefit of both. Writing in 1904, Eliot recalled that "wherever an [accreditation] association ... has been formed the relations between the secondary schools and colleges has proved to be one of the 
principle subjects of discussion" ("What" 757). Significantly, Harvard officials were involved in developing accreditation associations, and I contend this involvement resulted in accreditation associations' national advocacy for FYC.

By the mid-1880s, the importance of closer articulation among institutions was a pressing concern, and associations such as the National Education Association proliferated to meet the charge. ${ }^{14}$ The development of such associations indicates widespread attention being paid to articulation, but the first significant efforts to unite multiple institutions around articulation issues were taken in New England. In 1884, concurrent with Harvard's introduction of FYC, members of the Massachusetts Classical and High School Teachers' Association proposed “closer co-operation" between New England's secondary and post-secondary schools ("Editorial" 548; Tetlow). As a consequence, the New England Association of Colleges and Preparatory Schools (NEACPS) was formed for "the advancement of the cause of liberal education by the promotion of interests common to college and preparatory schools" (qtd. in Broome 129; Eliot, "What" 771). The NEACPS was an association of secondary and postsecondary officials, including Eliot, interested in articulation, and it eventually became the first regional accrediting body in America. One of the NEACPS's first acts was establishing a subcommittee, the Commission of Colleges in New England on Admission Examinations, to consider the wide variety of entrance requirements among colleges and universities and to devise options for managing it (First 5-6).

The Commission of Colleges was particularly important among associations involved with articulation. For one, the Commission's membership included such Ivy League icons as Harvard, Amherst, Brown, and Yale. ${ }^{15}$ Because of the Commission's high-profile membership, its actions garnered wide attention, even meriting popular newspaper reports (First 11). Among 
the Commission's earliest recommendations were that Vergil [sic], Latin Prose Composition, Homer, Greek Prose Composition, Geometry, French, and English Composition be pushed into the last year of secondary schools. "The intention of these recommendations was: (1) To assist the preparatory teachers in reserving work for their pupils as shall make a symmetrical course of study for the year immediately preceding admission to the college," and "(2) To prevent interruption in the study of subjects which will be continued after admission to college" (First 8). ${ }^{16}$ In effect, the Commission encouraged NEACPS members to strengthen articulation by designing the last year of secondary coursework to mirror closely the first year of postsecondary coursework—both of which included English composition.

Although the Commission's recommendations were advisory, not mandatory, they nevertheless shaped curricula at NEACPS member institutions. The effects can be seen in a letter sent by William Collar, president of Roxbury Academy in Boston, to President Eliot in 1886. Roxbury had long sent students to Harvard, but it also increasingly sent students to other colleges and prepared students for extra-collegiate pursuits. Collar writes, "I have received a circular stating the new [Harvard admission] requirements, and I am rejoiced to have the freedom that this scheme allows. We shall immediately introduce German and drop Greek composition. And shall keep all of Latin composition that is possible" ("Letter"). Harvard's curriculum-the recently established elective system—already met the Commission's recommendations, and Collar's letter indicates that Roxbury's curriculum would change to do the same. In other words, the Commission's recommendations advanced the articulation efforts in which Harvard was already engaged. Collar does not mention changes to Roxbury's English composition requirements—a significant amount was already required ("Returns")— but his letter indicates that the Commission's recommendations had direct consequences for NEACPS members. 
The Commission was widely influential beyond NEACPS members as well. According to the Report of the Commissioner of Education, 1886-1887, "The wide-spread interest which [the Commission's] deliberations have excited shows that the problems with which it has to deal affect the entire country, so that the solutions which prove sufficient for the exigencies of one section will be of practical advantage to the others" (509). Just a decade later, in 1897, the Commission's recommendations were "required for admission by 87 of the institutions of the country, from Maine to Oregon and from Minnesota to Missouri, 26 different states being represented" ("Requirements" 457). In fact, every major regional accreditation association adopted the Commission's English standards ("Requirements" 463-465; Eliot, "What"). Another 1897 report, "The Curriculum of the Land-Grant Colleges," recommended that land-grant colleges require "English grammar and composition, together with the English requirements of the New England Association" (Murkland 429). In essence, any secondary or post-secondary institution that joined an accreditation association was encouraged to orient around FYC to one degree or another by virtue of accreditation associations' sponsorship of the Commission's English standards.

The wide adoption of the Commission's English standards is telling because it reflects the predominance of articulation concerns throughout American education. Colleges, universities, and secondary schools were eager to address articulation concerns-precisely the concerns FYC was designed to address at Harvard. Moreover, Harvard officials played a central role in the NEACPS and the Commission of Colleges. In 1904, Eliot asserted:

In no department has the influence of the work of the Commission been more marked than English. It early secured a recognition of its recommendations in many colleges and schools all over the country, and for the past five or six years the improvements which it 
has introduced, chiefly determined by the principles formulated by Harvard College twenty-five years ago, have been adopted by the [accreditation] associations. ("What" 764)

Although he does not say so explicitly, it is not unreasonable to infer that those principles included FYC — either Harvard's version or something very like it. But whether Harvard officials expressly promoted FYC or not, accreditation associations supported a comparable model of first-year writing instruction as a mechanism for articulation. FYC did not cause articulation, but it enabled articulation by overtly linking secondary and post-secondary objectives and curricula. The Harvard model—via the Commission's English standards and accreditation associations' endorsement—proved sufficiently attractive for facilitating articulation and supporting students that it became the de facto option. Even granting the Commission's reluctance to compel members to adopt their recommendations (see "Editorial" 550; "Requirements" 463-465), it is clear that significant numbers of secondary and post-secondary institutions did, and quickly. In short, FYC addressed substantial institutional issues connected to articulation—recruitment, retention, standardization, curriculum reform, and more. As a result, accreditation associations advocated for first-year writing requirements, and FYC spread as rapidly across the country as accreditation.

\section{Articulation and Accreditation in the $21^{\text {st }}$ Century}

From an institutional perspective, it is clear that articulation and accreditation were primary drivers of first-year composition requirements in the late 1800s. I hasten to note this does not mean FYC was not considered "remedial," nor that FYC's institutional value prevented it from being instrumentalized as a "service." Indeed, it seems administrators were often less concerned with writing instruction than they were with FYC's institutional value. Nevertheless, 
major institutional forces shaped composition, and recognizing their formative effects can enlighten our understandings of theoretical and pedagogical innovation. Put differently, institutional histories like this one do not replace other histories, but rather indicate that a more systematic understanding of institutional issues is essential if we want to understand how composition came to exist.

This history has contemporary implications, as well. Articulation and accreditation have persisted since the NEACPS was established. In fact, they have evolved substantially and become more intricately intertwined with higher education. Articulation is recognizable in issues of transfer credits, dual enrollment, placement, and retention. Accreditation is increasingly prominent in discussions about for-profit institutions, MOOCs, and Federal financial aid. FYC is also inextricable from these issues - it was not separate from articulation and accreditation in the nineteenth century, and it is not separate now. As one example, several for-profit institutions, which are not accredited by traditional accreditation associations, offer low-cost composition courses with the insinuation that credits will transfer to traditionally accredited colleges and universities. Whether these courses do transfer to accredited institutions is generally a local concern, but the curricula often reflect recognizable composition scholarship, if usually rather poorly. Quality notwithstanding, composition nevertheless enables for-profits to recruit students via evocations of articulation and accreditation. Traditional institutions still direct discussions about articulation and accreditation, but as "higher education" options proliferate, FYC will surely continue to figure prominently in institutional, if not necessarily pedagogical, deliberations.

This is not the space to explore the manifold ways in which articulation and accreditation continue to affect FYC's existence in the current moment. But suffice to say, given the historical 
importance of institutional issues like articulation and accreditation in shaping first-year composition, scholars and teachers would be wise to explore institutional issues more thoroughly. Institutionally focused histories, in particular, can expose tensions that have resonated both within a particular institution and throughout American education. Understanding such tensions can expose our limits as teachers, scholars, and even administrators for influencing FYC; but they can also inform how we think and act in relation to the exigencies that institutions are compelled to address. ${ }^{17}$ In other words, whatever this return to Harvard tells us about the 1880s and 1890s, it is an invitation for rhetoric and composition specialists to become active in broader institutional conversations that affect the work we do. To decline the invitation is to accept the conditions that have historically shaped rhetoric and composition with or without our consent. 
Harvard, Again 20

\section{Notes}

${ }^{1}$ Many thanks to Matthew Heard, Kyle Jensen, Maureen Daly Goggin, Judy Holiday, David Fleming, and Duane Roen for their invaluable feedback on drafts of this essay. Thanks are also due to the University of North Texas's Office of Research and Economic Development, College of Arts and Sciences, and English Department for funding my visit to Harvard.

Harvard's archivists have my gratitude for their help in locating and accessing materials.

${ }^{2}$ The Harvard narrative can be briefly summed up as follows:

1869: Charles W. Eliot is appointed president at Harvard and gives his famous inaugural speech lamenting "the prevailing neglect of the systematic study of the English language" (“Inaugural" 2).

1872: Adams Sherman Hill, presumptive creator of first-year composition, becomes assistant professor of rhetoric.

1874: Harvard begins requiring an essay during the entrance exam. The results, which demonstrate students' shocking "illiteracy," provoke dismay among Harvard's professors (Connors 129).

1879: Hill publishes "An Answer to the Cry for More English," in which he calls for "the study [of English to] be taken up at the threshold of college life" (52).

1885: Harvard's “English A," precursor to modern FYC courses, becomes a first year requirement to address students' deficiencies.

1900: By all accounts, "Most colleges followed Harvard [in adopting] the freshman composition course that by 1900 had taken hold almost everywhere" (Brereton 13).

${ }^{3}$ Berlin also gestures to articulation, though he marks it emerging in the 1950s (107); and Arthur Applebee makes passing reference to articulation (72n29) and accreditation (41n30, 50). 
Berlin and Applebee see these issues as important, but only to contextualize specific inquiries into English studies.

${ }^{4}$ Other steps included raising tuition, expanding faculty, and attracting philanthropic donations. By the 1880s, Eliot was succeeding in most of these.

5 This speech was published in the Journal of Education in 1885. Page numbers refer to the published version.

${ }^{6}$ Eliot actually considered the distinction specious ("Present" 20).

${ }^{7}$ VanOverbeke details the developing tensions in American education. See also, Cremin, $\underline{\text { American and Transformation. }}$

${ }^{8}$ Colleges and universities represented a remarkably small segment of American education. In 1903, higher education of any sort enrolled less than 1/3 of one percent of America's population (Harris xix), and colleges and universities enrolled less than 1/6 of one percent (xiv). In comparison, elementary schools enrolled more than $20 \%$ of the population and secondary schools enrolled nearly $1 \%$ (xix). Enrollments do not represent the sum total of its influence, but higher education was not the driving force it later became (see Lucas, Chapter 5).

${ }^{9}$ Colleges, in general, were in danger of becoming obsolete (Lucas 149; Brereton 3; Eliot, "Address, Harvard"). There was even some suggestion around the turn of the twentieth century that colleges would eventually be squeezed out of existence altogether (see Brown 572; Brubacher and Rudy 250-251; Lazerson).

${ }^{10}$ There were discussions among at least ten New England colleges beginning as early as 1858 (Hanford).

${ }^{11}$ Eliot described rhetoric, German, French, chemistry, and physics as, “obviously matters which properly belong to the secondary schools," ("Annual Report, 1883-1884" 5) but 
there is no indication that composition was supposed to be abandoned. This runs counter to the prevailing belief that FYC was a temporary fix until secondary schools were upgraded, but there are a number of instances where Eliot reaffirms his belief that "The English language and literature are, or should be, studied from the beginning of the primary school to the end of the university course" (“Elementary” 35).

${ }^{12}$ Contrary to common belief, composition remained a requirement - though not a class - throughout students' entire course of study (see Committee on Rhetoric 2). In order to retain the elective system, composition became an extra-curricular requirement. Students attended lectures and wrote several "forensics" each year. It was hoped this system would "acquire something of the character of a regular course" and enable students to "treat of subjects that have a direct bearing upon their chosen studies" and bring elective work and forensics "into close relation with one another, to their mutual advantage" (“Annual Report, 1883-1884" 84). In other words, composition wasn't abandoned to the first year-it was separated from the formal curriculum so it could be required and tied to students' work throughout their course of study.

${ }^{13}$ Despite suggestions to the contrary, not all post-secondary institutions adopted FYC. Normal schools, for instance, largely resisted adopting FYC until the 1920s and 1930s (see Skinnell).

14 The nineteenth century saw an explosion in professional associations related to, but not coterminous with, education institutions. In New England, such associations had long existed (see Hanford). For just a small sampling of such associations, see "Requirements" 457.

15 The commission had fifteen original members: Amherst, Boston University, Bowdoin, Brown, Colby, Dartmouth, Harvard, Middlebury, Smith, Trinity, Tufts, Wellesley, Wesleyan, Williams, and Yale ("Requirements" 458). 
${ }^{16}$ The Second Annual Report offers additional points of interest. First, committee members argued that portfolios of high school writing should be considered valid evidence of college preparedness $(9,21)$. Second, there was much discussion about fairness on entrance examinations. Committee members argued it was unfair to expect students to be prepared for "the customary ex tempore composition." "If an entrance examination is deemed advisable, its limitations make it unwise to ask for continuous and well-sustained thought on themes that the candidate cannot satisfactorily anticipate" (9). In short, the recommendations are resonant with contemporary conversations in rhetoric and composition.

${ }^{17}$ For an example of how institutional issues can benefit writing classes, see Lester and Glau. 


\section{Works Cited}

"Annual Report of the President of Harvard University to the Overseers on the State of the University for the Academic Year 1876-1877." Cambridge: Wilson and Son, 1878.

"Annual Report of the President of Harvard University to the Overseers on the State of the University for the Academic Year 1882-1883.” Cambridge: Harvard UP, 1884.

"Annual Report of the President of Harvard University to the Overseers on the State of the University for the Academic Year 1883-1884.” Cambridge: Harvard UP, 1885.

"Annual Report of the President of Harvard University to the Overseers on the State of the University for the Academic Year 1885-1886." Cambridge: Harvard UP, 1887.

"Annual Report of the President of Harvard University to the Overseers on the State of the University for the Academic Year 1886-1887.” Cambridge: Harvard UP, 1888.

Applebee, Arthur N. Tradition and Reform in the Teaching of English: A History. Urbana: NCTE, 1974.

Berlin, James A. Rhetoric and Reality: Writing Instruction in American Colleges, 1900-1985. Carbondale: Southern Illinois UP, 1987.

Brereton, John C., ed. The Origins of Composition Studies in the American College, 1875-1925: A Documentary History. Pittsburgh: U Pittsburgh P, 1995.

Broome, Edwin Cornelius. A Historical and Critical Discussion of College Admission Requirements. New York: Columbia UP, 1902.

Brown, Elmer Ellsworth. "Secondary Education." Report of the Commissioner of Education, 1903, Volume 1. Washington DC: Office of Education, 1903.

Collar, William. "Action of the Colleges upon the Schools" Educational Review 2 (1891): 42241. 
---. Letter to Charles W. Eliot, Sept. 8, 1886. Records of President Charles W. Eliot. UAI 5.150, Folder “1886, C-E,” Box 13. Harvard University Archives.

Committee on Requisitions_for Entrance Examinations. Report of Committee Elective System and Att. At Recitations." Committee Report, 1886. HUC 8885.175. Harvard University Archives.

Committee on Rhetoric and English Literature. "Special Committee on Rhetoric and English Report to the Harvard Board of Overseers." Committee Report, Jan. 9, 1884. Records of the Board of Overseers. UAII 10.30.83.3. Harvard University Archives.

Connors, Robert J. Composition-Rhetoric: Backgrounds, Theory, and Pedagogy. Pittsburgh: University of Pittsburgh P, 1997.

Cremin, Lawrence A. American Education: The National Experience, 1783-1876. New York: Harper Colophon, 1982.

---. The Education of the Educating Professions. Washington D.C.: American Association of Colleges for Teacher Education, 1977.

---. The Transformation of the School: Progressivism in American Education, 1876-1957. New York: Knopf, 1961.

Donahue, Patricia. "Disciplinary Histories: A Meditation on Beginnings." In Donahue and Moon 220-36.

Donahue, Patricia and Gretchen Flesher Moon, eds. Local Histories: Reading the Archives of Composition. Pittsburgh: U of Pittsburgh P, 2007.

"Editorial." School and College: Devoted to Secondary and Higher Education. Ed. Ray Greene Huiling. Boston: Ginn \& Co (1892): 548-51. 
Eliot, Charles W. “Address at Classical and High School Teachers Association.” Speech, 1876. Records of President Charles W. Eliot. UAI 5.150, Folder 16, Box 216. Harvard University Archives.

---. "Address on the Elective System and of Francis Wayland as One of the Originators Thereof." Speech, 1885. Records of President Charles W. Eliot. UAI 5.150, Box 217, Folder 34. Harvard University Archives.

---. "Address at the Harvard Teachers Association Regarding Secondary Education.” Speech, 1903. Records of President Charles W. Eliot. UAI 5.150, Box 218, Folder 128. Harvard University Archives.

---. "Address at the Tenth Annual Convention of the Association of Colleges and Preparatory Schools." Speech Proceedings, 1896. Records of President Charles W. Eliot. UAI 5.150, Box 218, Folder 73. Harvard University Archives.

--- "The Elementary Schools, the High Schools, and the Colleges." Speech Proceedings, 1894. Records of President Charles W. Eliot. UAI 5.150, Box 217, Folder 53. Harvard University Archives.

---. "Entrance Examinations Not in Cambridge." Correspondence, 1882. Records of President Charles W. Eliot. UAI 5.150, Box 10. Harvard University Archives.

---. "Experience with a College Elective System." Speech, 1895. Records of President Charles W. Eliot. UAI 5.150, Box 217, Folder 62. Harvard University Archives.

---. "High School Programmes." Speech Proceedings, 1896. Records of President Charles W. Eliot. UAI 5.150, Box 218, Folder 72. Harvard University Archives.

---. "Inaugural Address as the President of Harvard College." Educational Reform: Essays and Addresses. Ed. Charles W. Eliot. New York: The Century Co. (1901): 1-38. 
---. "Present Relations of Mass. High Schools to Mass. Colleges." Speech, 1884. Records of President Charles W. Eliot. UAI 5.150, Box 217, Folder 33. Harvard University Archives. Published in Journal of Education 2 (1885): 19-20.

---. "Secondary School Programmes and the Conferences of the Committee of Ten." Essay, 1893. Records of President Charles W. Eliot. UAI 5.150, Box 217, Folder 50. Harvard University Archives.

---. "Shortening and Enriching the Grammar School Course." Speech Proceedings, 1892. Records of President Charles W. Eliot. UAI 5.150, Box 217, Folder 47. Harvard University Archives.

---. "What Has Been Gained in Uniformity of College Admission Requirements in the Past Twenty Years?” Speech Proceedings, 1904. Records of President Charles W. Eliot. UAI 5.150, Box 218, Folder 156. Harvard University Archives.

First Annual Report of the Commission of Colleges in New England on Admission Examinations, 1886-1887. Providence: Providence Press Co., 1887.

Fitzgerald, Kathryn. "A Rediscovered Tradition: European Pedagogy and Composition in Nineteenth-Century Midwestern Normal Schools." College Composition and Communication 53.2 (2001): 224-50.

Gannett, Cinthia, John C. Brereton, and Katherine E. Tirabassi. “'We All Got History'. Process and Product in the History of Composition." Pedagogy 10.2 (2010): 425-50.

Gold, David. Rhetoric at the Margins: Revising the History of Writing Instruction in American Colleges, 1873-1947. Carbondale: Southern Illinois UP, 2008.

Hanford, A. Chester. The Association of Colleges in New England: A Centennial History, 18581957. Cambridge, MA: Association of Colleges in New England, 1957. 
Harris, William T. “The Commissioner's Introduction.” Report of the Commissioner of Education, 1903, Volume 1. Department of the Interior. Washington DC: Government Printing Office, 1904.

The Harvard University Catalogue, 1884-1885. Cambridge, MA: College Press, 1884.

Hill, Adams Sherman. "An Answer to the Cry for More English.” In Brereton 45-56.

Lazerson, Marvin, ed. American Education in the Twentieth Century: A Documentary History. New York: Teachers College P, 1987.

Lester, Neal A. and Greg Glau. "Crow's Class-Size Order Yields Better Writing Students." Opinion. AZ Republic Online. 18 Jan 2008. Web. 23 Apr 2012.

Lucas, Christopher J. American Higher Education, A History. $2^{\text {nd }}$ ed. New York: Palgrave Macmillan, 2006.

Miller, Thomas P. The Evolution of College English: Literacy Studies from the Puritans to the Postmoderns. Pittsburgh: U of Pittsburgh P, 2011.

Morison, Samuel Eliot. The Development of Harvard University Since the Inauguration of President Eliot, 1869-1929. Cambridge, MA: Harvard UP, 1930.

Murkland, Charles S. "The Curriculum of the Land-Grant Colleges.” Report of the Commissioner of Education, 1896-1897, Volume 1. Washington DC: Office of Education (1897): 427-56.

Report of the Commissioner of Education, 1886-1887, Volume 1. Washington DC: Government Printing Office, 1888.

"Requirements for Admission to Freshman Class in Colleges, Universities, and Schools of Technology." Report of the Commissioner of Education, 1896-1897, Volume 1. Washington DC: Office of Education (1897): 457-63. 
"Returns from 20 Schools of the Time Spent on Elementary Greek, Advanced Greek, French of English, and English Composition.” Records of President Charles W. Eliot. UAI 5.150, Folder “1883, Preparatory School Studies,” Box 11. Harvard University Archives.

$\underline{\text { Second Annual Report of the Commission of Colleges in New England on Admission }}$ Examinations. Providence: Snow and Farnham, 1889.

Skinnell, Ryan. "Institutionalizing Normal: Rethinking Composition's Precedence in Normal Schools.” Composition Studies 41.1 (2013): 10-26.

Stewart, Donald C. “Harvard's Influence on English Studies: Perceptions from Three Universities in the Early Twentieth Century." College Composition and Communication 43.4 (1992): 455-71.

Strickland, Donna. The Managerial Unconscious in the History of Composition Studies. Carbondale: Southern Illinois UP, 2011.

Sullivan, Patricia. "Inspecting Shadows of Past Classrooms Practices: A Search for Students' Voices." College Composition and Communication 63.3 (2012): 365-86.

Tetlow, John. Letter to Charles W. Eliot, Apr. 12, 1885. Records of President Charles W. Eliot. UAI 5.150, Folder “1886, T-W,” Box 13. Harvard University Archives.

VanOverbeke, Marc A. The Standardization of American Schooling: Linking Secondary and Higher Education, 1870-1910. New York: Palgrave, 2008. 